\title{
Nucleotide Sequence of the $\beta$-Lactamase Gene of Alkalophilic Bacillus sp. Strain 170
}

\author{
By CHIAKI KATO, * TOSHIAKI KUDO, KAZUHO WATANABE AND \\ KOK I HORIKOSH I
}

The Riken Institute, Wako-shi, Saitama-ken 351-01, Japan

(Received 15 May 1985; revised 17 July 1985)

\begin{abstract}
A gene for the $\beta$-lactamase from alkalophilic Bacillus sp. strain 170 was cloned in a functional state on a $1.0 \mathrm{~kb}$ DNA fragment and its nucleotide sequence was determined. The coding sequence showed an open reading frame of 257 amino acids, which represents the $\beta$-lactamase precursor protein. It is considered that the signal peptide consisted of 30 amino acids including 12 hydrophobic amino acids.
\end{abstract}

\section{INTRODUCTION}

There have been several reports of the cloning of genes for extracellular enzymes from Bacillus strains. These include $\beta$-lactamases from $B$. licheniformis and B. cereus (Neugebauer et al., 1981 ; Sloma \& Gross, 1983). Each gene in which the nucleotide sequence has been determined has a region coding for a signal peptide at the $\mathrm{N}$-terminus. The signal peptide directs the protein through the cell membrane and is cleaved during the translocation process.

Recently, several genes of alkalophilic Bacillus sp. strains have been cloned in Escherichia coli or in B. subtilis (Kudo et al., 1983, 1985; Kato et al., 1984; Sashihara et al., 1984). $\beta$-Lactamase (penicillinase) is one of the secretory proteins produced by alkalophilic Bacillus sp. strain 170 (Sunaga et al., 1976). The DNA fragment containing the $\beta$-lactamase gene of this strain has been introduced into $E$. coli and has been shown to be strongly expressed (Kudo et al., 1983).

The nucleotide sequence of the $\beta$-lactamase gene is reported in this paper.

\section{METHODS}

Bacterial strains and plasmids. Alkalophilic Bacillus sp. strain 170 (FERM 3221), a producer of a $\beta$-lactamase in alkaline media, was isolated from soil (Sunaga et al., 1976). E. coli K12 strain HB101 Pro- leuB B lacY hsdRhsdM ala-14 galK2 xyl-5 mtl-1 supE44 $\mathrm{F}^{-}$endoI ${ }^{-}$recA Str $^{r}$ (Goldfarb et al.,1982) was used for transformation, and E. coli CSR603 thr-1 leuB6 proA2 phr-1 recAl argE3 thi-1 uvrA6 ara-14 lacY1 galK2 xyl-5 mtl-1 rpsL31 ts $x-33$ supE44 $\lambda^{-} \mathrm{F}^{-}$(Sancar \& Rupert, 1978) was used for the maxicell experiment.

Plasmids used were pBR325, pMB9 and pEAP2 (Kudo et al., 1983).

DNA preparation. Plasmid DNA was isolated from 1 litre of culture by the cleared lysate procedure (Boliver $e t$ al., 1977) and purified on a Bio-Gel A50 column (Blin \& Stafford, 1976). Slab gel electrophoresis and electroelution conditions were as described by Lawn et al. (1981).

Enzymes. RNAase and lysozyme were purchased from Sigma. Restriction endonucleases, DNA polymerase I (Klenow fragment) and T4 DNA ligase were obtained from BRL, and used according to the methods suggested by the manufacturer.

Transformation. E. coli transformations were done by the calcium shock procedure (Hershfield et al., 1974). Transformants were selected on LB plates supplemented with antibiotics at the appropriate concentration $(10 \mu \mathrm{g}$ ampicillin $\mathrm{ml}^{-1}$ and/or $50 \mu \mathrm{g}$ tetracycline $\mathrm{ml}^{-1}$ ).

Purification of $\beta$-lactamase and enzyme assay. Extracellular $\beta$-lactamase was purified from the culture filtrate of E. coli $\mathrm{HB} 101$ carrying pEAP2 as previously described (Kato et al., 1983). $\beta$-Lactamase was assayed by the method of Kudo et al. (1983). 

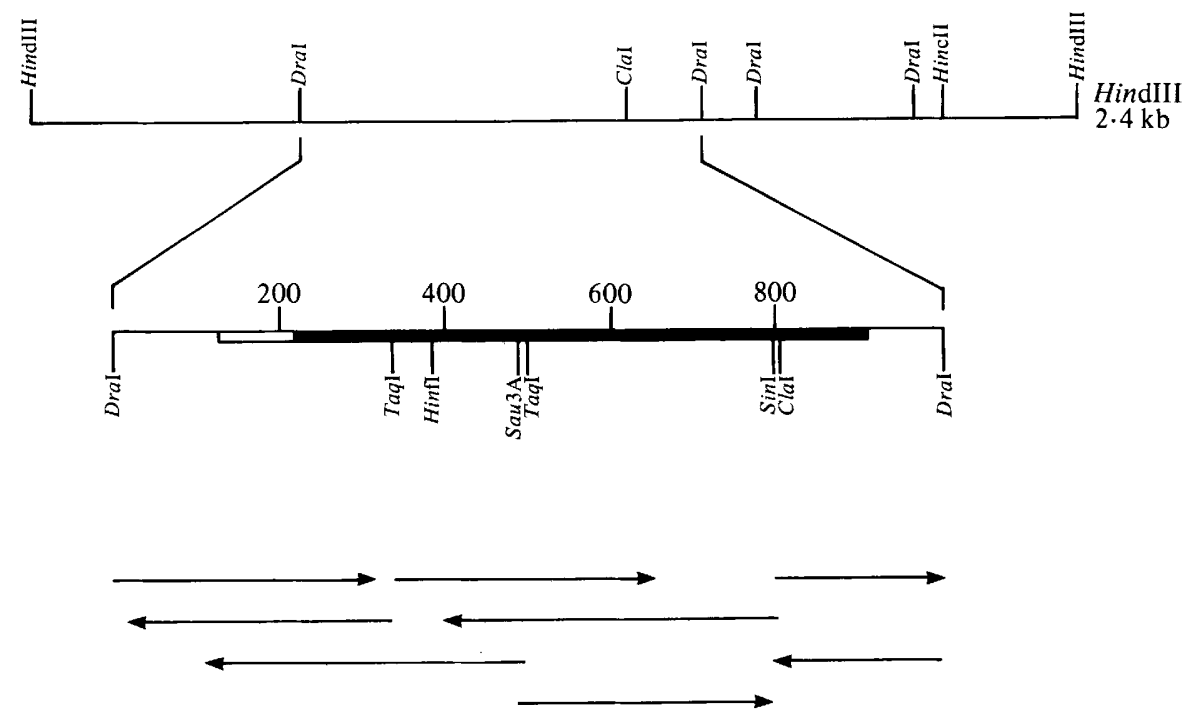

Fig. 1. Restriction map of the region surrounding the $\beta$-lactamase gene, and sequencing strategy. The cloned insert of pEAP2 is indicated as the $2.4 \mathrm{~kb}$ HindIII fragment. The filled box indicates the coding sequence for the mature protein, and the open box indicates the coding sequence of the signal peptide. The horizontal arrows indicate the sequencing strategy.

Maxicells. For the identification of plasmid-encoded polypeptide, a modification of the maxicell method described by Sancar $e t$ al. (1979) was used. After UV irradiation, the cells were incubated at $37^{\circ} \mathrm{C}$ with shaking in the presence of D-cycloserine $\left(100 \mu \mathrm{g} \mathrm{ml}^{-1}\right)$ for $12-16 \mathrm{~h}$. Labelling with $\mathrm{L}-\left[{ }^{35}\right.$ S $]$ methionine $\left(5 \mu \mathrm{Ci} \mathrm{ml}^{-1}\right.$; New England Nuclear) proceeded for $1 \mathrm{~h}$, after which the cells were washed with Hershey salts $(\mathrm{NaCl} 5.4 \mathrm{~g}, \mathrm{KCl} 3.0 \mathrm{~g}$, $\mathrm{NH}_{4} \mathrm{Cl} 1.1 \mathrm{~g}, \mathrm{CaCl}_{2} .2 \mathrm{H}_{2} \mathrm{O} 15 \mathrm{mg}, \mathrm{MgCl}_{2} .6 \mathrm{H}_{2} \mathrm{O} 0.2 \mathrm{~g}, \mathrm{FeCl}_{3} .6 \mathrm{H}_{2} \mathrm{O} 0.2 \mathrm{mg}, \mathrm{KH}_{2} \mathrm{PO}_{4} 87 \mathrm{mg}$ and Trizma base $12.1 \mathrm{~g}$ per litre of water, $\mathrm{pH} 7.4$ ), suspended in the lysis buffer and loaded directly onto the gel.

Amino acid analysis and sequencing. Amino acid analyses were done on a JEOL JLC-6AH amino acid analyser after hydrolysis of the protein samples in $6 \mathrm{M}-\mathrm{HCl}$ at $110^{\circ} \mathrm{C}$ for $24 \mathrm{~h}$. For the determination of methionine and cysteine, cyanogen bromide degradation and performic acid oxidation were used. The $\mathrm{N}$-terminal amino acid sequence was determined by a Beckman Protein/Peptide Sequencer 890-M (Edman \& Henschen, 1975). Amino acid phenylthiohydantoins were identified by a Hitachi 655 high pressure liquid chromatography system.

DNA sequencing. DNA sequencing was done by the dideoxy chain termination method (Sanger et al., 1977) using a long sequencing gel $(80 \times 20 \mathrm{~cm})$ if necessary. Specific restriction fragments were cloned into the $\mathrm{mp} 8$ or mp9 M13 vectors for dideoxy sequencing (Messing, 1981) by using $\left[\alpha-{ }^{35} \mathrm{~S}\right] \mathrm{dATP} \alpha \mathrm{S}$ (Amersham). The sequencing was done in both directions.

\section{RESULTS}

\section{DNA sequencing}

The gene for the $\beta$-lactamase of alkalophilic Bacillus sp. strain 170 was cloned in $E$. coli with pMB9. The plasmid pEAP2 thus constructed contained a $2.4 \mathrm{~kb}$ HindIII fragment (Kudo et al., 1983). The $\beta$-lactamase gene in the $2.4 \mathrm{~kb}$ HindIII fragment from pEAP 2 was recloned, and was found to be located in the $1.0 \mathrm{~kb}$ DraI fragment. The restriction endonuclease map of the $1.0 \mathrm{~kb}$ DraI fragment from pEAP2 is shown in Fig. 1, and the nucleotide sequence of the $\beta$-lactamase gene in Fig. 2. Analysis of the sequence showed that there was a single open reading frame of 771 $\mathrm{bp}$, from which a protein of molecular mass $27 \mathrm{kDal}$ could be translated.

\section{Determination of amino acid sequences}

Amino acid compositions of the extracellular form of $\beta$-lactamase are presented in Table 1. The values obtained by analysis of amino acids were mostly consistent with those calculated from the DNA sequence. Edman degradation showed that the sequence of $\mathrm{N}$-terminal amino acids of the extracellular $\beta$-lactamase was $\mathrm{NH}_{2}$ Ser-Gln-Lys-Val-Glu-Gln-Ile-Val-Ile-Lys-Asn- 
ATGAAAAAGAATACGTTGTTAAAAGTAGGATTATGTGTAAGTTTACTAGGAACAACTCAATTTGTTAGCACGATT MetLysLysAsnThrLeuLeuLysValGl yLeuCy SVa I SerLeuLeuGl y ThrThrGInPheVal SerThr I 1 e $(-30)$

TCTTCTGTACAAGCATCACAAAAGGTAGAGCAAATAGTAATCAAAAATGAGACGGGAACCATTTCAATATCTCAG

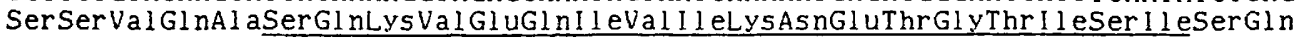
(1)

$\operatorname{Taq} \mathrm{I}$

225

TTAAACAAGAATGTATGGGTTCATACGGAGTTAGGTTATTTTAATGGAGAAGCAGTTCCTTCGAACGGTCTAGTT LeuAsnLysAsnVal TrPVal Hi SThrGluLeuGl yT yrPheAsnGl yGluAlaVal ProSerAsnGl yLeuVal

CTTAATACTTCTAAAGGGCTAGTACTTGTTGATTCTTCTTGGGATAACAAATTAACGAAGGAACTAATAGAAATG LeuAsnThrSerLysGl yLeuValLeuVal As PSerSerTr PAsPAsnLysLeuThrLysGluLeuI l eGI uMet

$$
\text { Sau3A TaqI }
$$

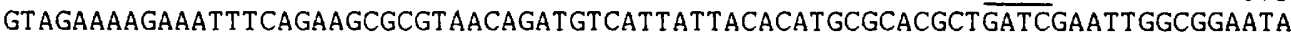
ValGluLysLysPheGInLysArgVal ThrAspVal I l eI l eThrHisAl aHisAlaAspargI leGl yGly I le

ACAGCGTTGAAAGAAAGAGGCATTAAAGCGCATAGT ACAGCATTAACCGCAGAACTAGCAAAGAAAAGT GGATAT ThrAl aLeuLysGl UArgGl y I eLysAl aHi sSerThrAl aLeuThrAl aGluLeuAl aLysLysSerGl yTyr

GAAGAGCCACTTGGAGATTTACAAACAGT TACGAATTTGAAGTTTGGCAAT ACAAAAGTAGAAACGTTCTATCCA GI UGl UProLeuGl yAs PLeuGInThrVal ThrAsnLeuLysPheGl yAsnThrLysValGluThrPheTyrPro

GGGAAAGGACATACAGAAGATAATATTGTTGTTTGGTTGCCACAATATCAAATTTTAGCTGGAGGCTGTTTAGTA Gl yLysGl yHi SThrGluAs PAsnI l eVal Val TrPLeuProGl nTyrGI nI l eLeuAl aGl yGl yCysLeuVaI

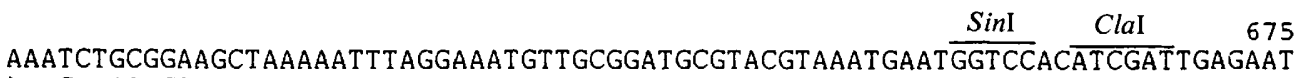
LysSerAl aGIUAl aLysAsnLeuGl yAsnVal Al aAs PAI a TyrValAsnGI UTr PSerThrSer I l eGluAsn

ATGCTGAAGCGATATAGAAATATAAATTTGGTAGTACCTGGTCACGG 750 MetLeuLysArgTyrArgAsn I leAsnLeuValValProGlyHisGl yLysValGl yAspLysGl yLeuLeuLeu

CATACATTGGATTTATTAAAATAAGAAATTGTAGAAATACAAAAGAGAGGAGAAATAATTTTCTCCTCTCTTTC

HisThrLeuAs PLeULeuLYS**** $(22.7)^{*}$



Fig. 2. Complete nucleotide sequence of the alkalophilic Bacillus sp. strain $170 \beta$-lactamase gene and the primary structure of its product. The 18 amino acids corresponding to the determined amino terminus of the extracellular $\beta$-lactamase are underlined. The amino acids are numbered taking the $\mathrm{N}$-terminal amino acid of the mature protein as (1). The putative terminator sequence is underlined. The ShineDalgarno (SD) sequence is indicated by broken lines.

Glu-Thr-Gly-Thr-Ile-Ser-Ile. This amino acid sequence is identical to that deduced from the DNA sequence. Therefore, 30 amino acid residues (residues -30 to -1 ) are considered to represent the signal peptide which is removed during secretion of the $\beta$-lactamase.

\section{Analysis of the gene products}

The maxicell strain E. coli CSR603 carrying pBR325, pMB9 or pEAP2 was irradiated with UV light to destroy the chromosomal DNA. Proteins encoded by the plasmids in these strains were analysed on SDS-polyacrylamide gels after incorporation of $\mathrm{L}-\left[{ }^{35} \mathrm{~S}\right] \mathrm{methionine} \mathrm{(Fig.} \mathrm{3).} \mathrm{No}$ incorporation of label into protein occurred in the parent strain CSR603 after irradiation. The strain carrying pBR325 produced proteins of molecular mass $35 \mathrm{kDal}, 28 \mathrm{kDal}$ and $23 \mathrm{kDal}$, 


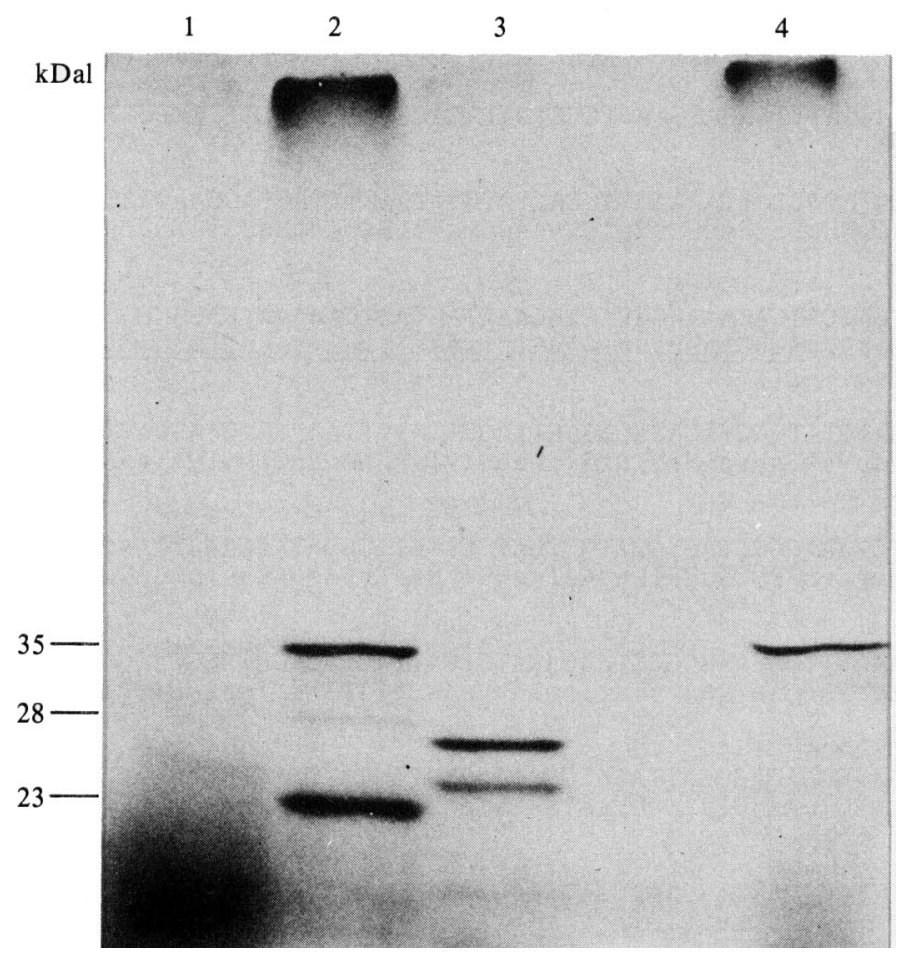

Fig. 3. Autoradiogram of $\left[{ }^{35} \mathrm{~S}\right]$ methionine-labelled proteins made in E. coli CSR603 (lane 1), and E. coli CSR603 carrying pBR325 (lane 2), pEAP2 (lane 3) and pMB9 (lane 4). Tcr (35 kDal), Ap ${ }^{r}(28 \mathrm{kDal}$ ) and $\mathrm{Cm}^{\mathrm{r}}(23 \mathrm{kDal})$ gene products from pBR325 were used as the molecular mass markers.

Table 1. Amino acid composition of mature $\beta$-lactamase

$\begin{array}{lcclcc}\begin{array}{c}\text { Amino } \\ \text { acid }\end{array} & \begin{array}{c}\text { Amino acid } \\ \text { analysis }\end{array} & \begin{array}{c}\text { From DNA } \\ \text { sequence }\end{array} & \begin{array}{c}\text { Amino } \\ \text { acid }\end{array} & \begin{array}{c}\text { Amino acid } \\ \text { analysis }\end{array} & \begin{array}{c}\text { From DNA } \\ \text { sequence }\end{array} \\ \text { Lys } & 22 & 22 & \text { Ala } & 14 & 13 \\ \text { His } & 7 & 7 & \text { Cys } & 1 & 1 \\ \text { Arg } & 5 & 5 & \text { Val } & 20 & 21 \\ \text { Asx* } & 26 & 25 & \text { Met } & 2 & 2 \\ \text { Thr } & 18 & 17 & \text { Ile } & 13 & 14 \\ \text { Ser } & 12 & 12 & \text { Leu } & 26 & 6 \\ \text { Glx* } & 24 & 23 & \text { Tyr } & 5 & 4 \\ \text { Pro } & 3 & 5 & \text { Phe } & 4 & \text { ND } \\ \text { Gly } & 20 & 20 & \text { Trp } & \text { Th }\end{array}$

* Asx represents Asp and Asn; Glx represents Glu and Gln. ND, Not determined.

corresponding to the products of the $\mathrm{Tc} \mathrm{c}^{\mathrm{r}}, \mathrm{Ap}^{\mathrm{r}}$ and $\mathrm{Cm}^{\mathrm{r}}$ genes, respectively. A $\mathrm{Tc}^{\mathrm{r}}$ gene product was also detected in the strain carrying pMB9. Cells carrying pEAP2, which contained the insert in the $\mathrm{Tc}^{\mathrm{r}}$ gene of pMB9, lacked the $35 \mathrm{kDal}$ protein, and bands of about $27 \mathrm{kDal}$ and $24 \mathrm{kDal}$, which corresponded to the precursor and extracellular $\beta$-lactamase, were observed.

\section{DISCUSSION}

We have reported the sequencing of the gene for $\beta$-lactamase from alkalophilic Bacillus sp. strain 170. The identification of this gene as that for $\beta$-lactamase is unambiguous because (1) the cloned DNA can transform a Pen ${ }^{\mathrm{s}}$ form to $\mathrm{Pen}^{\mathrm{r}}$ (Kudo et al., 1983) and (2) it contains a codon 

A. MetLysLeuTrPPheSerThrLeuLysLeuLysLysAl aAl aAl aVa l LeuLeuPheSer 120
B. MetMet 1 leLeuLysasnLysArgMetLeuLys I leGly I leCysVal Gl y I l eLeuGly
C. MetLysLysAsnThrLeuLeuLys/ValG1yLeuCysVal SerLeuLeuglyThrThrGin
A. Cysvalal a LeuAlaglyCys Ala AsnAsnglnThrasnal a SerGinProAlagluLys I-ExoL 30
B. LeuSer I l eThrSerLeuGIuAl aPheThrGI yGl uSerLeuGI nValGluAl aLysGlu $30 \bullet$
C. PhevalserThrileSerServalginala SerGin

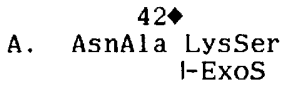

B. LysThrGlyglnval Lys His Lys Asngin
\end{abstract}

Fig. 4. Comparison of the signal sequences of $\beta$-lactamase in Bacillus strains. A, B. licheniformis $\beta$ lactamase (Kroyer \& Chang, 1981); B, B. cereus $\beta$-lactamase I (Mezes et al., 1983); C, alkalophilic Bacillus sp. strain $170 \beta$-lactamase. $\bullet$, Cutting site of signal peptide (ExoL and ExoS indicate the processing sites for the primary and secondary exo- $\beta$-lactamase cleavage products, respectively) (Simons et al., 1978; Izui et al., 1980); M४, cutting site that yields the membrane bound form of the enzyme; $v$, possible cutting sites of the signal peptide. Hydrophilic and basic amino acids near the $\mathrm{N}$ terminal of the signal peptide are underlined. The pentapeptide around the cysteine residue is boxed (see discussion). The amino acids are numbered taking the $\mathrm{N}$-terminal amino acid of the signal peptide as (1).

sequence of 18 amino acids deduced to be identical to the determined $\mathrm{N}$-terminal sequence of the mature $\beta$-lactamase.

The molecular mass of the protein derived from the $771 \mathrm{bp}$ open reading frame beginning with the first ATG coincided with the molecular mass of the precursor $\beta$-lactamase. The precursor and mature $\beta$-lactamase possess three and two methionine residues respectively. Considering this, the ratio of precursor to mature $\beta$-lactamase was about 1 in this maxicell system (Fig. 3). The precursor and mature $\beta$-lactamase were observed in this system, suggesting that the enzyme was processed by an $E$. coli processing system.

The precursor $\beta$-lactamase possesses an extra, 30 amino acid, peptide, corresponding to the difference in molecular weight between the precursor and mature $\beta$-lactamase. This initial peptide has a sequence that has similar properties to other identified signal peptides (Kreil, 1981). It has a segment that is basic, with lysine residues at -29 and -28 , followed by a series of hydrophobic amino acids. The residue at the cleavage site (residue -1 ) is alanine. The signal sequence of the $\beta$-lactamase was compared with those of $\beta$-lactamases from other Bacillus strains (Fig. 4). A proportion of the $\beta$-lactamases from $\mathrm{Gram}$-positive organisms are membrane-bound (Nielsen \& Lampen, 1982). In $B$. licheniformis this binding is achieved through a glyceride thioether modification of the cysteine in the signal peptide sequence (Lai et al., 1981). A cysteine residue was also observed in the signal sequence of the alkalophilic Bacillus sp. strain $170 \beta$ lactamase. The amino acid sequence around the cysteine of the $\beta$-lactamase is Val-Gly-Leu-Cys$\mathrm{Val}$. This sequence is similar to that reported for $B$. cereus $\beta$-lactamase I (Ile-Gly-Ile-Cys-Val) but different from that reported for $B$. licheniformis $\beta$-lactamase (Leu-Ala-Gly-Cys-Ala).

From the DNA sequence analysis, the $\beta$-lactamase gene of alkalophilic Bacillus sp. strain 170 had no homology with that of $B$. licheniformis, but had partial homology with that of $B$. cereus in 
A.

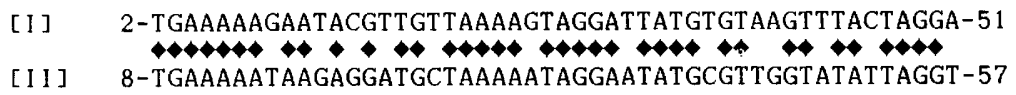

C.

[1] 538-AC-AGAAGATAATATTGTTGTTTGGTT--GCCAC--AATAT--CA--AATTTTAG-583

[II] 781-ACAAGAA-ATGATATTGCTGTC--GTTTGGCCTCCAAATAGTGCACCAATTATCG-832

Fig. 5. DNA sequence comparison between the alkalophilic Bacillus sp. strain $170 \beta$-lactamase gene [I] and the $B$. cereus $\beta$-lactamase I gene [II]. A, B and C show three regions containing partial DNA homology. Homologous nucleotides are connected with $\bullet$. The nucleotides are numbered taking the first nucleotide of the initiation codon as (1). The sequences of the B. cereus gene are taken from Sloma \& Gross (1983).



Fig. 6. Amino acid sequence homology between the sequence around the histidine and cysteine residues of the alkalophilic Bacillus sp. strain $170 \beta$-lactamase [I] and the B. cereus $\beta$-lactamase II (class B enzyme) [II]. A, B, C and D show four regions of amino acid sequences around the histidine and cysteine residues. Homologous amino acids are connected with $\bullet$. The amino acids are numbered taking the $\mathrm{N}$-terminal amino acid of the mature protein as (1). The amino acid sequences of $B$. cereus $\beta$ lactamase II are taken from Ambler (1980).

three regions (Fig. 5). One of these was found in the signal peptide region of the gene (Fig. 5A). The $\beta$-lactamase of alkalophilic Bacillus sp. strain 170 looks like a class B enzyme according to the classification system proposed by Ambler (1980), because strong homology was observed between the sequences around the histidine and cysteine residues of $B$. cereus $\beta$-lactamase II (Ambler, 1980) and the amino acid sequence of $\beta$-lactamase of alkalophilic Bacillus sp. strain 170 (Fig. 6). These results support the idea that alkalophilic Bacillus sp. strain 170 is closely related to $B$. cereus. 
An examination of the sequences preceding and following the coding regions shows several features of interest. The initial methionine is preceded by a possible ribosome binding site sequence (near nucleotide -10 ) which has homology with $B$. subtilis $16 \mathrm{~S}$ rRNA (Fig. 2).

Following the termination codon of $\beta$-lactamase there is one inverted repeat structure (nucleotides 792-823) which could play a role in transcription termination. This sequence is followed by a T-rich region which is similar to termination structures seen in $E$. coli (Rosenberg \& Court, 1979).

This work was partially supported by a Grant for Life Science Promotion from the Riken Institute.

\section{REFERENCES}

AMBLER, R. P. (1980). The structure of $\beta$-lactamases. Philosophical Transactions of the Royal Society of London B289, 321-331.

BLIN, N. \& STAFFORD, D. W. (1976). A general method for isolation of high molecular weight DNA from eukaryotes. Nucleic Acids Research 3, 23032308.

Boliver, F., Rodoriguez, R. L., Greene, P. J., Betlach, M. C., Heynecker, H. L. \& Boyer, H. W. (1977). Construction and characterization of new cloning vehicles. II. A multipurpose cloning system. Gene 2, 95-113.

Edman, P. \& Henschen, A. (1975). Sequence determination. In Protein Sequence Determination, 2nd edn, pp. 232-279. Edited by S. B. Needleman. Berlin: Springer-Verlag.

Goldfarb, D. S., Rodoriguez, R. L. \& DoI, R. H. (1982). Translation block to expression of the Escherichia coli $\mathrm{Tn}-9$ derived chloramphenicol-resistance gene in Bacillus subtilis. Proceedings of the National Academy of Sciences of the United States of America 79, 5886-5890.

Hershfield, V., Boyer, H. W., Yanofsky, C., Lovett, W. A. \& Helinsky, D. R. (1974). Plasmid ColEl as a molecular vehicle for cloning and amplification of DNA. Proceedings of the National Academy of Sciences of the United States of America 71, 3455-3459.

Izui, K., Nielsen, J. B. K., Caulfield, M. P. \& LAMPEN, J. O. (1980). Large exopenicillinase, initial extracellular form detected in cultures of Bacillus licheniformis. Biochemistry 19, 1882-1886.

Kato, C., Kudo, T., Watanabe, K. \& Horikoshi, K. (1983). Extracellular production of Bacillus penicillinase by Escherichia coli carrying pEAP2. European Journal of Applied Microbiology and Biotechnology 18, 339-343.

Kato, C., Kudo, T. \& Horikoshi, K. (1984). Gene expression and production of Bacillus No. 170 penicillinase in Escherichia coli and Bacillus subtilis. Agricultural and Biological Chemistry 48, 397-401.

KREIL, G. (1981). Transfer of proteins across membranes. Annual Review of Biochemistry 50, 317348.

Kroyer, J. \& Chang, S. (1981). The promoterproximal region of the Bacillus licheniformis penicillinase gene: nucleotide sequence and predicted leader peptide sequence. Gene 15, 343-347.

Kudo, T., Kato, C. \& HoRikoshi, K. (1983). Excretion of the penicillinase of an alkalophilic
Bacillus sp. through the Escherichia coli outer membrane. Journal of Bacteriology 156, 949-951.

Kudo, T,, Yoshitake, J., Kato, C., Usami, R. \& Horikoshi, K. (1985). Cloning of a developmentally regulated element from alkalophilic Bacillus subtilis DNA. Journal of Bacteriology 161, 158-163.

LaI, J.-S., Sarvas, M., Brammer, W. J., Neugebauer, K. \& WU, H. (1981). Bacillus licheniformis penicillinase synthesized in Escherichia coli contains covalently linked fatty acid and glyceride. Proceedings of the National Academy of Sciences of the United States of America 78, 3506-3510.

Lawn, R. M., Adelman, J., Franke, A. E., Houck, C. M., Gross, M., NaJarian, R. \& Goeddel, D. V. (1981). Human fibroblast interferon gene lacks introns. Nucleic Acids Research 9, 1045-1052.

Messing, J. (1981). In Third Cleveland Symposium on Macromolecules: Recombinant DNA, pp. 143-153. Edited by A. Walton. Amsterdam: Elsevier.

MeZes, P. S. F., Yang, Y. Q., Hussain, M. \& Lampen, O. (1983). Bacillus cereus 569/H $\beta$-lactamase I: cloning in Escherichia coli and signal sequence determination. FEBS Letters 161, 195-200.

Neugebauer, K., Sprengel, R. \& Schaller, H. (1981). Penicillinase from Bacillus licheniformis: nucleotide sequence of the gene and implications for the biosynthesis of a secretory protein in a Grampositive bacterium. Nucleic Acids Research 9, 25772588

Nielsen, J. B. K. \& Lampen, J. O. (1982). Membrane bound penicillinases in gram-positive bacteria. Journal of Bacteriology 257, 4490-4495.

RosenberG, M. \& COURT, D. (1979). Regulatory sequences involved in the promotion and termination of RNA transcription. Annual Review of Genetics 13, 319-353.

SANCAR, A., HaCk, A. M. \& RUPP, W. D. (1979). Simple method for identification of plasmid-coded proteins. Journal of Bacteriology 137, 692-693.

SANCAR, A. \& RUPERT, C. S. (1978). Determination of plasmid molecular weights from ultraviolet sensitivities. Nature, London 272, 471-472.

Sanger, F., Nicklen, S. \& Coulson, A. R. (1977). DNA sequence with chain-terminating inhibitors. Proceedings of the National Academy of Sciences of the United States of America 74, 5463-5467.

Sashihara, N., Kudo, T. \& Horikoshi, K. (1984). Molecular cloning and expression of cellulase genes of alkalophilic Bacillus sp. strain N-4 in Escherichia coli. Journal of Bacteriology 158, 503-506. 
Simons, K., Sarvas, M., Garoff, H. \& Helenius, A. (1978). Membrane bound and secreted forms of penicillinase from Bacillus licheniformis. Journal of Molecular Biology 126, 673-690.

Sloma, A. \& Gross, M. (1983). Molecular cloning and nucleotide sequence of the type I $\beta$-lactamase gene from Bacillus cereus. Nucleic Acids Research 11, 4997-5004.

Sunaga, T., Akiba, T. \& Horikoshi, K. (1976). Production of penicillinase by an alkalophilic Bacillus. Agricultural and Biological Chemistry 40, $1363-$ 1367. 